\title{
Pemanfaatan Bakteri Selulolitik Sekum Kelinci dengan Aras Konsentrasi Koloni dan Waktu Inkubasi untuk Fermentasi Limbah Agroindustri Lokal dalam Pakan Kelinci
}

\author{
U. Ali dan M. F. Wajdi \\ Fakultas Peternakan, Universitas Islam Malang Jl. Tirtomulyo 64, Landungsari, DAU, Malang 65151 \\ E-mail:usmanchalim50@yahoo.co.id
}

\begin{abstract}
ABSTRAK
Tujuan penelitian adalah untuk mengisolasi, mengkarakterisasi dan membuat kultur bakteri selulolitik dari sekum kelinci yang akan digunakan untuk fermentasi limbah agroindustri lokal KKO (kulit daging kelapa, kulit biji kedelai dan onggok), dengan menggunakan aras konsentrasi dan waktu inkubasi, sehingga menjadi produk pakan berkualitas dan palatabel sebagai pakan pengganti bahan komersial untuk optimasi performan kelinci. Materi penelitian sekum kelinci dan limbah KKO. Metode penelitian deskriptif untuk hasil isolasi, karakterisasi dan pembuatan kultur bakteri selulolitik sekum, dilanjutkan penelitian fermentasi KKO menggunakan rancangan acak lengkap (RAL) factorial $3 \times 5$ dengan konsentrasi koloni bakteri selulolitik $\left(\mathrm{Ki}=10^{7} \mathrm{CFU} / \mathrm{g}\right.$ bahan, $\mathrm{K}_{2}=10^{8} \mathrm{CFU} / \mathrm{g}$ bahan, $\mathrm{K}_{3}=$ $10^{9} \mathrm{CFU} / \mathrm{g}$ ) dan lama inkubasi (I1= 2 hari, $\mathrm{I} 2=4$ hari $\mathrm{I} 3=6$ hari $\mathrm{I} 4=8$ hari, $\mathrm{I} 5=10$ hari). Hasil penelitian bakteri selulolitik dari epitel dinding sekum bersifat gram positif, tidak membentuk spora, katalase negatif dan berbentuk basil. Perlakuan konsentrasi koloni bakteri dan lama inkubasi fermentasi KKO secara parsial menurunkan BO, LK, SK, NDF, ADF dan selulosa, tetapi meningkatkan PK. Perlakuan interaksi meningkatkan PK dan nutrien lain turun tidak nyata. Perlakuan efektif interaksi konsentrasi $10 \mathrm{CFU} / \mathrm{g}$ BK dan lama inkubasi 8 hari dengan PK 11,55\%; SK 17,34\%; LK 31,29\%; NDF 28,23\%; ADF 18,33\% dan selulosa 8,89\%. Bakteri selulolitik sekum kelinci dari epitel dinding sekum bersifat gram positif, tidak berspora, katalase negatif dan berbentuk basil. Kandungan nutrien KKOF terbaik pada perlakuan K2I8 dengan PK meningkat 14,36\% dan nutrien lain turun SK 17,39\%; LK 0,73\%; NDF 15,53\% dan selulosa 25,74\%. Efektifitas fermentasi KKO menggunakan bakteri selulolitik sekum kelinci dengan konsentrasi $10^{8} \mathrm{CFU} / \mathrm{g}$ BK bahan dan lama inkubasi 8 hari.
\end{abstract}

Kata kunci: bakteri selulolitik sekum kelinci, limbah KKO, fermentasi, kandungan nutien

\section{Utilization of Rabbit Caecum Cellulolytic Bacteria in Fermentation of Local Agroindustry Waste As Feed Rabbit}

\begin{abstract}
This study aims to isolation, characterization and create a culture of cellulolytic bacteria from the caecum of rabbits to fermentation local agro-industry waste CSO (skin coconut meat, soybean seed coat and onggok) into quality feed products and palatable as a commercial feedstuff substitute for optimization performance of rabbit. The materials of study are rabbit caecum, culture media and waste CSO. The study methods is descriptive of isolation, characterization and creation of caecum cellulolytic bacterial culture, continued experiments using a completely randomized design (CRD) factorial $3 \times 5$ fermentation of cellulolytic bacteria colonies concentration $(\mathrm{Ci}=10 \mathrm{CFU} / \mathrm{g} \mathrm{DM}, \mathrm{C} 2$ $\left.=10^{8} \mathrm{CFU} / \mathrm{g} \mathrm{DM}, \mathrm{C} 3=10^{9} \mathrm{CFU} / \mathrm{g} \mathrm{DM}\right)$ and a long incubation ( $\mathrm{Ii}=2$ days, $I 2=4$ days,$I_{3}=6$ days, $I_{4}=8$ days, $I_{5}=10$ days). The results show that cellulolytic bacteria strongest from epithelial wall of caecum are gram-positive, do not form spores, catalase negative and bacillus. The nutrient content of waste CSO: CP 10.11\%; CF 20.99\%; EE 31.52\%; NDF 33.42\%, ADF 21,35\% and cellulose $11.97 \%$ so need to be fermented. Treatment of bacterial colonies concentration and long
\end{abstract}


incubation in fermentation CSO partially lowered $O M, E E, C F, N D F, A D F$ and cellulose, but increase the CP. Treatment interaction increases $C P$ and other nutrients down not significant. Effective treatment interaction concentration $10^{8} \mathrm{CFU} / \mathrm{g} D M$ and long incubation 8 days with $C P 11.55 \%$; $C F$ 17.34\%; EE 31.29\%; NDF 28.23\%; ADF 18:33\% and cellulose $8.89 \%$. In conclusion, the strongest rabbit caecum cellulolytic bacteria from the epithelial wall of the caecum are gram positive, not sporulating, catalase negative and formed bacillus. Nutrient content of the best CSOF at $\mathrm{K}_{2} \mathrm{I}_{8}$ treatment with CP increased $14.36 \%$ and other nutrients down: CF 17.39\%; EE 0.73\%; NDF 15.53\% and cellulose. $25.74 \%$. Suggested fermentation effectiveness CSO waste can use the caecum cellulolytic bacteria concentration of $10 \mathrm{CFU} / \mathrm{g}$ DM material and incubation time of 8 days.

Keywords: CSO waste, fermentation, nutrient content.

\section{PENDAHULUAN}

Limbah agroindustri lokal di kota Batu dan pinggiran Malang melimpah. Limbah tersebut diantaranya kulit daging kelapa dari industri santan kelapa, kulit biji kedelai dari industri tempe, onggok dari industri tepung tapioka, ampas apel dari industri sari apel, ampas tahu dan bekatul dari penggilingan padi. Limbah ini melimpah dan kadang dibuang begitu saja, sehingga menuurunkan estetika lingkungan, namun berpotensi sebagai pakan kelinci. Kombinasi kulit daging kelapa, kulit biji kedelai dan onggok (KKO) sangat cocok untuk pakan sumber energi, namun karena ketiganya berupa limbah maka mempunyai kandungan serat kasar tinggi (20,99\%). Agar campuran bahan pakan limbah lebih berdaya guna, tidak tengik dan lebih palatabel maka perlu diolah melalui biofermentasi (Rakhmani, 2005). Biofermentasi menggunakan bakteri selulolitik dari isolat bakteri sekum kelinci diharapkan menghasilkan enzim yang mampu bekerja secara sinergis dalam mendekomposisi serat kasar dan anti nutrisi menjadi bahan metabolit, tambahan nitrogen sel, aneka enzim cerna dan produk pakan yang palatabel karena aroma harum spesifik (Purwadaria dan Sari, 2007). Hal ini dapat menggantikan proses fermentasi pakan secara internal dalam digester sekum kelinci, sehingga pakan lebih efisien.

Kendala utama dalam usaha peternakan intensif yaitu biaya pakan tinggi mencapai $70 \%$, hal ini karena kebutuhan pakan harus disediakan dalam kandang dan ternak tidak perlu diumbar untuk mencari makan sendiri. Alternatif menekan biaya pakan dengan menggunakan bahan pakan yang tidak bersaing kebutuhan manusia seperti limbah agroindustri lokal terutama kulit daging kelapa (Cocos nucifera), kulit biji kedelai (Glycine max) dan onggok (Manihot esculenta) sebagai upaya mengurangi penggunaan pollard (Triticum aestivum) atau bungkil kelapa yang mahal dalam pakan untuk optimasi performan produksi kelinci. Selain itu pemilihan bahan pakan harus cukup tersedia dan harga murah, sehingga dapat memberi keuntungan peternak. Kelinci sebagai pseudoruminasi dengan digester mikrobial sekum seperti pada kuda sehingga toleransi terhadap serat kasar pakan mencapai lebih $12 \%$ dan protein rendah 14 - 15\% relatif sama dengan termak ruminansia (Ensminger et al., 1990).

Pemanfaatan KKO sebagai sumber bahan pakan kelinci dapat ditingkatkan dengan cara biofermentasi. Fermentasi akan optimum dengan syarat yang tertentu, sehingga berapa konsentrasi koloni bakteri dan waktu inkubasi untuk menghasilkan pakan KKO fermentasi menarik untuk diteliti.

\section{METODE PENELITIAN}

\section{Metode Penelitian}

Metode penelitian secara deskriptif untuk seleksi dan karakterisasi bakteri selulolitik sekum kelinci. Penelitian fermentasi KKO menggunakan rancangan acak lengkap pola faktorial $3 \times 5$ dengan 
Tabel 1. Karakterisasi, uji endospore, katalase pada isolat sekum kelinci

\begin{tabular}{|c|c|c|c|c|c|c|c|}
\hline \multirow[t]{2}{*}{ Isolat } & & & \multicolumn{5}{|c|}{ Uji karakterisasi } \\
\hline & & Gram & Bentuk & Endospora & Katalase & Tumbuh & Zona bening \\
\hline ESI & & + & basil & - & - & + & + \\
\hline ES2 & & - & basil & - & - & & \\
\hline ES3 & & + & basil & - & - & -/+ & - \\
\hline ES4 & L & + & basil & - & - & + & + \\
\hline ES5 & & - & kokus & - & - & & \\
\hline DS1 & & - & basil & - & - & & \\
\hline DS2 & & + & basil & - & - & & - \\
\hline DS3 & & + & basil & - & - & + & + \\
\hline $\mathrm{CS} 1$ & & + & kokus & - & - & & \\
\hline $\mathrm{CS} 2$ & & + & basil & - & - & - & - \\
\hline
\end{tabular}

Keterangan: $\mathrm{ES}=$ epitel sekum $\quad$ DS $=$ digesta sekum $\quad \mathrm{CS}=$ cairan sekum

ulangan sampel 3 kali. Faktor penelitian yang digunakan konsentrasi koloni bakteri selulolitik $\left(\mathrm{K} 1=10^{7} \mathrm{CFU} / \mathrm{g}\right.$ bahan, $\mathrm{K} 2=10^{7}$ $\mathrm{CFU} / \mathrm{g}$ bahan, $\left.\mathrm{K} 2=10^{9} \mathrm{CFU} / \mathrm{g}\right)$ dan lama inkubasi $(\mathrm{I} 1=2$ hari, $\mathrm{I} 2=4$ hari $\mathrm{I} 3=6$ hari $\mathrm{I} 4=8$ ha $\mathrm{I} 5=10$ hari.

Bakteri diambil dari epitel sekum (ES), digesta sekum (DS) dan cairan sekum (CS) kelinci dan diisolasi dengan cara menumbuhkan bakteri selulolitik dengan media MRS-CMC. Isolat untuk karakterisasi dipilih 6 spesies terbaik, yaitu isolat ES1, ES3, ES4, DS2, DS3 dan CS2. Isolat diuji potensinya sebagai bakteri selulolitik secara kualitatif menggunakan media padat metode gores dan diamati kemampuan tumbuhnya dan indikator zona bening pada media MRSCMC agar diberi pewarna congo red.

KKO difermentasi menggunakan koloni bakteri selulolitik terpilih secara in vitro sesuai perlakuan penelitian pada kondisi optimum dan hasil fermentasi dianalisis kandungan $\mathrm{BO}, \mathrm{PK}, \mathrm{LK}, \mathrm{SK}$, NDF. ADF, selulose dan lignin.

\section{Analisis Statistik}

Hasil seleksi dan karakterisasi bakteri selulolitik sekum kelinci menggunakan pendekatan metode deskriptif. Data hasil fermentasi ditabulasi dan dianalisis menggunakan sidik ragam dan dilanjutkan uji jarak Duncan's (UJD) untuk mengetahui perbedaan antar perlakuan (Yitnosumarto, 1990).

\section{HASIL DAN PEMBAHASAN}

Hasil menunjukkan karakterisasi isolat bakteri bersifat gram positif, tidak membentuk spora, katalase negatif dan berbentuk basil. Isolat ES1, ES4 dan DS3 terbukti mampu tumbuh pada CMC dengan baik dan sanggup menunjukkan zona bening sekitar koloni. Ketiga isolat ini sebagai bakteri selulolitik dominan, sedang isolat ES3 dan DS2 juga sebagai selulolitik dapat tumbuh pada media MRS-CMC dengan baik, namun tidak tampaknya zona bening sekitar koloni disebabkan tebalnya media yang berada diantara koloni dan permukaan media. Hal ini sesuai pernyataan Barrow and Weldham (1993) karakter bakteri selulolitik yaitu gram positif, tidak membentuk spora, katalase negatif, facultative anaerob, fermentatif, bentuk batang dan bulat.

Hasil karakterisasi isolat bakteri dari epitel dinding sekum, digesta dan cairan sekum kelinci tampak pada Tabel 1 .

Kandungan BO, PK, LK dan SK dalam KKOF

Hasil penelitian konsentrasi koloni bakteri selulolitik dan lama inkubasi fermentasi KKO berpengaruh sangat nyata $(\mathrm{P}<0,01)$ dan tidak berinteraksi terhadap kandungan $\mathrm{BO}, \mathrm{PK}, \mathrm{LK}$, dan $\mathrm{SK}$, namun pada PK meningkat nyata (Tabel 2).

Semakin meningkat konsentrasi bakteri selulolitik dan makin lama inkubasi fermentasi KKO menurunkan kandungan BO, LK dan SK, tetapi pada PK naik. 
Tabel 2. Kandungan BO, PK, LK dan SK (\%) perlakuan penelitian

\begin{tabular}{lcccc}
\multicolumn{1}{c}{ Perlakuan $(\%)$} & BO & PK $(\%)$ & LK $(\%)$ & SK $(\%)$ \\
\hline Konsentrasi & & & & \\
$\mathrm{C}_{1}\left(10^{7} \mathrm{CFU} / \mathrm{g} D M\right)$ & $94,37 \pm 1,23^{\circ}$ & $10,29 \pm 0,30^{\mathrm{a}}$ & $31,42 \pm 0,13^{\mathrm{b}}$ & $19,04 \pm 1,88^{\mathrm{b}}$ \\
$\mathrm{C}_{2}\left(10^{8} \mathrm{CFU} / \mathrm{g} D\right)$ & $93,57 \pm 1,27^{\mathrm{a}}$ & $10,81 \pm 0,83^{\mathrm{b}}$ & $31,33 \pm 0,19^{\mathrm{a}}$ & $18,56 \pm 1,72^{\mathrm{a}}$ \\
$\mathrm{C}_{3}\left(10^{9} \mathrm{CFU} / \mathrm{g} D M\right)$ & $92,96 \pm 1,38^{\circ}$ & $11,38 \pm 1,25^{\mathrm{c}}$ & $31,27 \pm 0,25^{\mathrm{a}}$ & $18,39 \pm 1,77^{\mathrm{a}}$ \\
$\mathrm{Inkubasi}$ & & & & \\
$\mathrm{I}_{2}(2$ days $)$ & $95,21 \pm 0,95^{\circ}$ & $10,41 \pm 1,21^{\mathrm{a}}$ & $31,44 \pm 0,06^{\mathrm{c}}$ & $20,14 \pm 0,77^{\mathrm{d}}$ \\
$\mathrm{I}_{4}(4$ days $)$ & $94,74 \pm 1,45^{\circ}$ & $10,58 \pm 0,91^{\mathrm{ab}}$ & $31,39 \pm 0,09^{\mathrm{bc}}$ & $19,47 \pm 0,85^{\mathrm{c}}$ \\
$\mathrm{I}_{6}(6$ days $)$ & $93,34 \pm 1,39^{\mathrm{b}}$ & $10,78 \pm 0,78^{\mathrm{b}}$ & $31,33 \pm 0,12^{\mathrm{b}}$ & $18,73 \pm 0,91^{\mathrm{b}}$ \\
$\mathrm{I}_{8}(8$ days $)$ & $92,62 \pm 1,32^{\mathrm{a}}$ & $11,16 \pm 0,99^{\mathrm{c}}$ & $31,31 \pm 0,15^{\mathrm{ab}}$ & $17,57 \pm 1,68^{\mathrm{a}}$ \\
$\mathrm{I}_{10}(10$ days $)$ & $92,27 \pm 1,32^{\circ}$ & $11,18 \pm 1,08^{\mathrm{c}}$ & $31,23 \pm 0,21^{\mathrm{a}}$ & $17,39 \pm 1,07^{\mathrm{a}}$ \\
\hline
\end{tabular}

Kandungan BO, LK dan SK terendah pada K3 berturutan 92,96, 31,27 dan 18,39\% dan pada lama inkubasi 10 hari sebesar 92,27, 31,23 dan $17,39 \%$. Nilai BO, LK dan SK tertinggi pada K1 berurutan 94,37, 31,42 dan $19,04 \%$ dan lama inkubasi 2 hari berurutan sebesar 95,21, 31,44 dan 20,14\%. Penurunan nutrien ini disebabkan oleh aktifitas hidrolitik bakteri selama fermentasi untuk menguraikan senyawa komplek menjadi bentuk sederhana. Bakteri selulolitik mensekresi enzim selulase memecah selulosa menjadi selubiosa dan glukosa yang dapat menyediakan nutrien bagi ternak (Arora, 1995). Enzim selulase mendegradasi selulosa yang merupakan komponen SK, pada K3 dan semakin lama inkubasi mengakibatkan penurunan SK 21,0 \% menjadi $18,39 \%$. Kandungan BO menurun seiring perubahan nilai LK, SK dan PK karena ketiganya komponen $\mathrm{BO}$ selain BETN.

$\begin{array}{ccc} & \text { Peningkatan kandungan } & \text { PK seiring } \\ \text { dengan } & \text { meningkatnya } & \text { konsentrasi }\end{array}$ penggunaan koloni bakteri dan lama inkubasi produk KKOF disebabkan oleh adanya penambahan nitrogen dari biomassa sel bakteri selama inkubasi yang tumbuh dan berkembang. Pada konsentrasi K3 dan lama inkubasi lebih lama maka biomassa sel bakteri semakin bertambah mengakibatkan kandungan nitrogen dan PK meningkat. Hal ini didukung hasil penelitian Sutrisno et al. (2005) bahwa fermentasi ampas teh terjadi peningkatan kandungan PK yang disebabkan peningkatan biomassa sel mikroba yang kaya protein. Sel mikroba mengandung PK 31-78
$\%$ yang dapat digunakan sebagai sumber protein alternatif bagi ternak (Triwiyono, 1996).

Kandungan PK terendah pada Kl $10,29 \%$ dan terbesar pada K3 11,38\% dan pada L10 11,18 \%, berarti perlakuan fermentasi ini dapat meningkatkan kandungan $\mathrm{PK}$ menjadi 12,58 \% (PK sebelum fermentasi 10,11\%). Peningkatan PK pada KKOF ini masih lebih kecil dibandingkan hasil penelitian Rakhmani (2005) fermentasi onggok menggunakan kapang Aspergillus niger menghasilkan produk fermentasi PK 15\%. Hal ini disebabkan fermentasinya menggunakan media tambahan nitrogen anorganik seperti urea dan mineral amonium sulfat, selain itu dapat tambahan nitrogen dari fiksasi $\mathrm{N}$ dan biomassa sel mikroba yang tumbuh berkembang selama fermentasi.

Hasil uji jarak Duncan (UJD) menunjukkan bahwa antara K3 dan K2 berpengaruh sama terhadap kadar $\mathrm{BO}$, LK dan SK kecuali pada PK dan berbeda K1, sedang lama inkubasi L10 dan L8 berpengaruh sama terhadap kandungan $\mathrm{BO}$, PK, LK dan SK dan berbeda L2, L4 dan L6. Selanjutnya perlakuan kombinasi paling efektif dan ekonomis adalah interaksi antara konsentrasi $10^{8} \mathrm{CFU} / \mathrm{g}$ BK bahan dan inkubasi 8 hari, selain itu fermentasi secara anaerobik dapat mencegah kontaminasi mikroba pembusuk.

Interaksi antara konsentrasi dan lama inkubasi berpengaruh sangat nyata $(\mathrm{P}<0,01)$ terhadap kandungan $\mathrm{PK}$ tetapi pada kandungan BO, LK dan SK tidak nyata. 

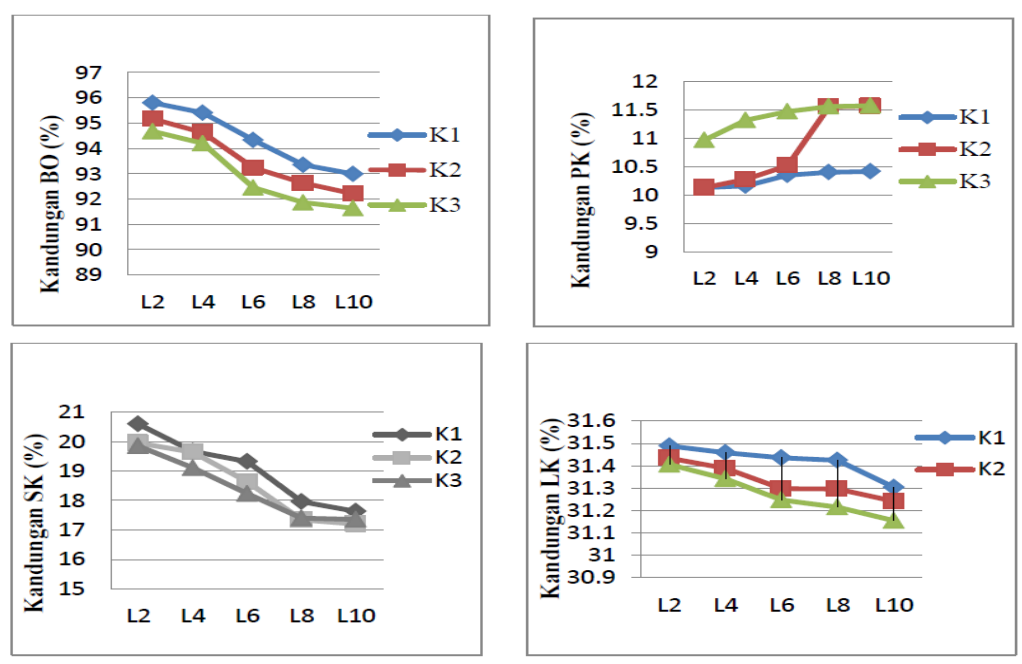

Gambar 1. Interaksi BO, PK, LK, SK penelitian

Berdasarkan Gambar 1 menunjukkan tidak ada interaksi antar perlakuan konsentrasi dan lama inkubasi terhadap kandungan $\mathrm{BO}$, LK dan SK, sedang pada kandungan PK ada interaksi yang signifikan. Makin meningkat konsentrasi koloni bakteri $\left(10^{7}-10^{9} \quad \mathrm{CFU} / \mathrm{g} \quad \mathrm{BK}\right.$ bahan) dan lama inkubasi 2-10 hari menurunkan kandungan BO, LK dan SK, namun pada PK bertambah. Semakin meningkat penggunaan konsentrasi koloni bakteri dan lama inkubasi, maka makin bertambah enzim diekskresikan, sehingga hal ini akan meningkatkan konsentrasi enzim. Menurut Pelczar and Chan (1986) semakin meningkat konsentrasi enzim maka semakin bertambah aktifitasnya sehingga semakin cepat dan banyak substrat yang dapat diuraikannya menjadi komponen lebih sederhana.

\section{Kandungan NDF. ADF, Selulose dan Lignin dalam KKOF}

Hasil penelitian menunjukkan konsentrasi bakteri selulolitik dan lama inkubasi berpengaruh sangat nyata $(\mathrm{P}<0,01)$ pada kandungan NDF, ADF dan selulosa, namun tidak nyata pada kandungan lignin. Perlakuan kombinasi konsentrasi koloni bakteri dan lama inkubasi tidak berpengaruh nyata terhadap kandungan NDF, ADF, selulosa dan lignin.
Rataan kandungan NDF, ADF, selulosa dan lignin dalam KKOF disajikan pada Tabel 3.

Peningkatan konsentrasi bakteri selulolitik dan lama inkubasi fermentasi KKO dapat menurunkan kandungan NDF, ADF, selulosa dan lignin KKOF. Kandungan NDF, DF dan selulosa terendah pada K3 berurutan 30,18, 19,59 dan 10,29\% dan nilai terbesar pada K1 berurutan 29,32, 19,16 dan $11,38 \%$. Faktor lama inkubasi menunjukkan kandungan NDF, ADF dan selulosa terendah pada lama inkubasi 10 hari berurutan 28,29, 18,20 dan $10,41 \%$, dan terbesar pada lama inkubasi 2 hari berurutan 31,45, 20,61 dan $11,19 \%$. Hal ini menunjukkan bahwa konsentrasi bakteri rendah dan lama inkubasi singkat maka aktifitas degradasi substrat komplek serat belum maksimal yang berarti kualitas produk fermentasi KKOF kurang baik. Menurut Cai et al. (1999) aktifitas mikroba selulolitik mensekresikan enzim endoglukanase atau carboxymethyl cellulase (CMC-ase), eksoglukanase dan figlukosidase. Ketiga jenis enzim ini secara sinergis mendegradasi selulosa menjadi glukosa. Enzim CMC-ase memecah ikatan hidrogen dalam struktur kristal selulosa sehingga terbentuk rantai individu selulosa, eksoglukanase memotong ujung rantai individu selulosa, sehingga menghasilkan disakarida dan tetrasakarida seperti selobiosa dan fi-glukosidase menghidrolisis disakarida dan tetrasakarida menjadi glukosa. 
Tabel 3. Rataan kandungan NDF, ADF, sellulose dan lignin KKOF

\begin{tabular}{|c|c|c|c|c|}
\hline Perlakuan & NDF (\%) & ADF $(\%)$ & Selulose (\%) & Lignin $(\%)$ \\
\hline \multicolumn{5}{|l|}{ Konsentrasi } \\
\hline $\mathrm{K}_{1}\left(10^{7} \mathrm{CFU} / \mathrm{g} \mathrm{BK}\right)$ & $30,18 \pm 1,57^{b}$ & $19,59 \pm 1,48^{\mathrm{b}}$ & $10,10 \pm 0,97$ & $7,14 \pm 0,04$ \\
\hline $\mathrm{K}_{2}\left(10^{8} \mathrm{CFU} / \mathrm{g} \mathrm{BK}\right)$ & $29,35 \pm 1,29^{\mathrm{a}}$ & $19,33 \pm 1,40^{\mathrm{ab}}$ & $09,81 \pm 1,15^{\mathrm{ab}}$ & $7,13 \pm 0,03$ \\
\hline $\mathrm{K}_{3}\left(10^{9} \mathrm{CFU} / \mathrm{g} \mathrm{BK}\right)$ & $29,32 \pm 1,03^{\mathrm{a}}$ & $19,16 \pm 1,47^{\mathrm{a}}$ & $09,64 \pm 1,13^{\mathrm{a}}$ & $7,13 \pm 0,02$ \\
\hline \multicolumn{5}{|l|}{ Inkubasi } \\
\hline $\mathrm{I}_{2}(2$ hari $)$ & $31,45 \pm 0,01^{\mathrm{d}}$ & $20,61 \pm 0,29 \mathrm{~d}$ & $11,23 \pm 0,09 \mathrm{~d}$ & $7,14 \pm 0,03$ \\
\hline $\mathrm{I}_{4}$ (4 hari) & $30,50 \pm 0,67^{\mathrm{c}}$ & $20,13 \pm 0,36^{\mathrm{c}}$ & $10,66 \pm 0,46$ 。 & $7,14 \pm 0,02$ \\
\hline $\mathrm{I}_{6}(6$ hari $)$ & $29,27 \pm 0,82^{b}$ & $19,47 \pm 0,53^{b}$ & $09,81 \pm 0,43$ & $7,13 \pm 0,03$ \\
\hline $\mathrm{I}_{8}(8$ hari $)$ & $28,56 \pm 0,52^{\mathrm{a}}$ & $18,39 \pm 0,34^{\mathrm{a}}$ & $09,02 \pm 0,54^{\mathrm{a}}$ & $7,13 \pm 0,03$ \\
\hline $\mathrm{I}_{10}(10$ hari $)$ & $28,29 \pm 0,25^{\mathrm{a}}$ & $18,20 \pm 0,19^{\mathrm{a}}$ & $08,53 \pm 0,30^{\mathrm{a}}$ & $7,13 \pm 0,02$ \\
\hline
\end{tabular}

Hasil UJD menunjukkan bahwa perlakuan $\mathrm{K} 3$ dan $\mathrm{K} 2$ berpengaruh sama dan berbeda dengan $\mathrm{K} 1$ terhadap kadar NDF, ADF dan selulosa. Substrat NDF, ADF, selulosa dan lignin sebagai penyusun dinding sel tanaman selain hemiselulosa dan silika. Keberadaan selulosa dan hemiselulosa dalam bahan pakan dapat menghambat pencernaan enzimatis tubuh, tetapi dapat didegradasi secara mikrobial oleh aktifitas mikroba cellulomonas sebagai bakteri selulolitik yang mensekresikan enzim selulase. Penurunan kandungan NDF, ADF dan selulosa seiring meningkatnya konsentrasi koloni bakteri dan lama inkubasi, hal ini menunjukkan bahwa aktifitas bakteri selulolitik pengurai serat berlangsung terus selama fermentasi. Bakteri secara ekstraseluler dapat merombak selulosa, hemiselulosa dan lignin, karena fraksi serat tidak larut air. Menurut Peres et al (2002) mikroorganisme memiliki dua tipe sistem kerja enzim ekstraseluler yaitu sistem hidrolitik yang menghasilkan hidrolase yang merespon terhadap perombakan selulosa dan hemiselulosa, dan kedua sistem oksidatif dan lignolitik ekstraseluler unik untuk depolimerisasi lignin. Hemiselulosa sebagai komponen NDF merupakan polisakarida heterogen yang dihubungkan selulosa dan lignin pada dinding sel tanaman dan beberapa jenis mikrobia mampu merombak menjadi gula dan asam asetat. Xilan merupakan karbohidrat utama penyusun hemiselulosa (Tillman et al., 1989). Perombakan hemiselulosa memerlukan berbagai macam enzim hidrolitik yaitu endo1,4-fi-xylanase (endoxylanase), acetyl esterase, a-glukuronidase dan fi-xylosidase, enzim tersebut secara acak akan menyerang ikatan glikosidik.

Perlakuan berpengaruh non signifikan terhadap kandungan lignin, hal ini disebabkan lignin mempunyai ikatan glikosidik yang sulit didegradasi oleh enzim mikroba. Flagel and Meetivison (1988) menyatakan bahwa lignin adalah polimer dari phenil prophyl membentuk jaringan ikat kompleks bersifat water resistant, amourphous dan berikatan kuat dengan polisakarida, selulosa dan hemiselulosa dalam dinding sel tanaman dan merupakan bahan proteksi sempurna. Lignin adalah faktor paling penting dalam membatasi ketersediaan pakan untuk hewan herbivora dan sistem digesti anaerobik. Lignin membentuk struktur polimer tiga dimensi unit phenylpropane, struktur pertama coumeryl alcohol, conyferyl alcohol dan sinaphyl alcohol. Lignin banyak terdapat pada batang berkayu dan rumput-rumputan yang menguatkan batang.

\section{SIMPULAN DAN SARAN}

Simpulan yang dapat diambil adalah: (1) Isolat bakteri sellulolitik dari sekum yang paling kuat adalah dari sampel epitel dinding sekum dan digesta sekum, bersifat gram positif, tidak membentuk spora, katalase negatif dan berbentuk basil, (2) Fermentasi menggunakan starter bakteri selulolitik sekum konsentrasi $10 \mathrm{CFU} / \mathrm{g}$ BK bahan dengan lama inkubasi 8 hari mengoptimasi peningkatan kualitas limbah agroindustri 
lokal KKO. Saran untuk penelitian berikutnya adalah uji biologis penggunaan produk pakan fermentasi limbah agroindustri lokal KKOF untuk optimasi performan kelinci dan nilai ekonomis pakan secara in vivo.

\section{DAFTAR PUSTAKA}

Arora, S.P. 1983. Microbial digestion in ruminants. India Council Agricultural. Research. New Delhi.

Barrow, G.I. and R.K.A. Weldham. 1993. Manual for identification of medical bacteria. Cowan and Steel's, Eds. Cambridge University Press.

Cai, Y.J., S.J. Chapman, J.A. Buswell, and S.T. Chang. 1999. Production and distribution of endoglucanase, cellobiohydrolase, and P-glucosidase components of the cellulolytic system of Volvariella volvacea, the edible straw mushroom. App. and Env. Microb. 65(2): 553-559.

Ensminger, M.E., J.E. Oldfield and W.W. Heinemann. 1990. Feed and nutrition. $2^{\text {nd }}$ ed. The Ensminger Pub., Co.. Clovis.

Flagel and Meetivision. 1998. Livestock and feeding. $4^{\text {th }}$ ed. Durham and Doney, Oregon, USA.

Pelczar, M.J. and E.C.S. Chan. 1986. Dasardasar mikrobiologi. Penterjemah: R.S.
Hadioetomo, T. Imas dan S.S Tjitrosomo. UI Press, Jakarta.

Peres, J., J. Munoz-Dorado, T.D. Rubia, and J. Martinez. 2002. Biodegradation and biological treatment of cellulose, hemicellulose and lignin: An overview. Int. J. Microbiol. 5: 53-56.

Purwadaria, T. dan L. Sari. 2007. Pengkajian nilai gizi hasil fermentasi mutan Aspergillus niger pada substrat bungkil kelapa dan bungkil inti sawit. Biodiversitas. 5(2): 48-51.

Rakhmani, S. 2005. Peningkatan nilai gizi bahan pakan dari limbah pertanian melalui fermentasi. Dalam: Proseding Lokakarya Nasional Potensi dan Peluang Pengembangan Usaha Agribisnis Kelinci. BPT. Ciawi. Bogor. hal. 66-74.

Sutrisno, Pujaningsih dan Sumarsih. 2005. Kajian kualitas ampas teh yang difermentasi menggunakan Aspergillus niger dengan lama pemeraman yang berbeda. Dalam: Prosiding Seminar Nasional AINI ke V. hal. 247-253.

Tillman, A.D., H. Hartadi, S. Reksohadiprodjo, S. Prawirokusumo dan S. Lebdosoekojo. 1989. Ilmu makanan ternak dasar. Gadjah Mada University Press, Yogyakarta.

Yitnosumarto, S. 1990. Percobaan, perancangan, analisis dan interpretasinya. Universitas Brawijaya. Program MIPA, Malang. 